Zbigniew Tucholski

Instytut Historii Nauki im. L. i A. Birkenmajerów PAN

\title{
INŻYNIER HENRYK GENELLO (1872-1948), SZKIC DO PORTRETU ZAPOMNIANEGO ARCHITEKTA KOLEJOWEGO
}

\author{
Henryk Genello, engineer (1872-1948), \\ an outline for portrait of a forgotten railway architect
}

Henryk Genello was an architect who rendered great service for the Polish railway architecture during the 2nd Polish Republic. Together with engineer and architect Hipolit Hryncewicz, he designed around 50 railway stations in the Eastern borderlands, in the Vilnius Headquarters of the State Railways. In the 20s of the 20th century, he was designing in national style, while at the end of the 20s his designs already bore distinct modernist traits, and in the 30 s they became totally functionalist. A valuable realisation of Genello and Hryncewicz was a representative "modernised" railway station on the border in Stołpce, essential for the evolution of Polish railway architecture of the 2nd Polish Republic. At the turn of the 20s and 30s of the 20th century, Genello designed railway stations on the Ustron - Wisła line. They were realised in national style, partly wooden, inspired by the Polish mountain resort architecture of Zakopane. Another important Genello's realisation of 1935 was a small building of a railway stop - Zułów, which in the 2nd Polish Republic had a memorative character of Marshall Piłsudski silhouette. It probably was the last "national" realisation in the Polish railway architecture. His works done in this style were characterised by simplicity, pure form, and drew on local types and motives of Polish architecture. Undoubtedly, Henryk Genello was better fulfilled when he designed in the earlier, historicising style, creating his own type inspired by local motives. His later functional realisations are characterised by simplicity, pared-down and austere form of elevations deprived of detail. It is certain that Genello belonged to the most important railway architects of the 2nd Polish Republic, working since 1932 as adviser in the Ministry of Transport, he shaped railway architecture of that time from its administrative and technical side. The same function Genello performed during the first years after the war. 
Keywords: Henryk Genello, history of railway architecture of the 2nd Polish Republic, national style, modernism, railways in the Eastern borderland

Słowa kluczowe: Henryk Genello, historia architektury kolejowej II RP, styl narodowy, modernizm, kolejnictwo na kresach

Badania dziejów architektury kolejowej w okresie II RP są prowadzone są przez historyków sztuki i architektury, a także historyków komunikacji i techniki ${ }^{1}$. Najbardziej komplementarne ujęcie historii rozwoju utylitarnej architektury kolejowej powinno obejmować analizę formy architektonicznej obiektów, połączoną z badaniami ich funkcji, z uwzględnieniem rozwoju techniki kolejowej. W wielu wypadkach wartościową architektoniczną formę otrzymywały bowiem obiekty o stricte technicznym przeznaczeniu, jak: parowozownie, warsztaty kolejowe, elektrowozownie i podstacje trakcyjne, wagonownie, wieże wodne, pompownie, wagi wagonowowe, nastawnie, posterunki blokowe oraz posterunki zwrotniczych. Forma ta była bowiem dopełnieniem technicznej funkcji tych utylitarnych obiektów. Analiza rozwoju i przemian architektury kolejowej wymaga również przedstawienia szerokiego historycznego tła powstania i rozwoju sieci kolejowej na ziemiach polskich. W wielu wypadkach pomimo narodowej formy budynków wznoszonych w latach 20. XX w., ich układ funkcjonalny warunkowały wcześniejsze przepisy i normatywy budowlane zaborczych zarządów kolejowych jeszcze z końca XIX w.

Istotną przeszkodą utrudniającą badania w zakresie historii architektury kolejowej II RP jest zniszczenie i rozproszenie w wyniku wojny, a także w okresie powojennym i w czasie transformacji dokumentacji międzywojennego Departamentu Budowy i Utrzymania Ministerstwa Komunikacji oraz poszczególnych Działów Budynków Dyrekcji Kolei Państwowych.

Ustalenie dokładnej daty powstania poszczególnych obiektów, a także ich autorstwa, napotyka często na znaczne trudności. Wiele wartościowych realizacji powstałych na sieci PKP w II RP pozostaje do dziś całkowicie anonimowa. Przykładem tego mogą być wiaty i poczekalnie na linii otwockiej oraz grodziskiej, zbudowane podczas elektryfikacji Warszawskiego Węzła Kolejowego w 1936 r., których projektant z kręgu pracowników Biura Projektów i Studiów PKP pozostaje nadal niestety

\footnotetext{
${ }^{1}$ Najważniejsze publikacje dotyczące architektury kolejowej II RP: Obiekty kolejowe: układy przestrzenne, architektura, elementy techniki, red. nauk. W. C z a r n e cki, M. Pron i e w s ki, Białystok 2005, ss. 313; M. Ps z c zółkowski: Architektura użyteczności publicznej II Rzeczypospolitej 1918-1939. Funkcja, Łódź 2015, ss. 280; Por. Piękne użyteczne zbędne... Obiekty kolejowe w Polsce, red M. Kwapia s, D. Keller, Rybnik 2016, ss. 528. Propozycja typologii architektury kolejowej II RP została sformułowana przez M. Pszczółkowskiego, badania w tym zakresie prowadzi również Michał Jerczyński; por. tego autora, Architektura obiektów kolejowych na liniach kolei Warszawsko-Wiedeńskiej - ewolucja stylu od 1845 r. do dziś, referat na Sesji popularno-naukowej „Dziedzictwo Wiedenki”, Muzeum Techniki i Przemysłu NOT, 11 czerwca $2015 \mathrm{r}$.
} 
nieznany $^{2}$. Już w latach 20. i 30. XX w. budynki kolejowe były często projektowane przez kilku architektów w kolejowych biurach projektowych, dziś wobec braku oryginalnej dokumentacji określenie ich autorstwa jest niezwykle trudne ${ }^{3}$.

Zawodowe biografie i dorobek wielu architektów kolejowych, zatrudnionych w poszczególnych Działach Budynków Dyrekcji Kolei Państwowych, nadal czekają na badaczy. Nie powstały dotychczas biografie tak istotnych dla architektury kolejowej II RP architektów, jak Romuald Miller, Eugeniusz Szretter ${ }^{4}$, czy Józef Wołkanowski. Artykuł ten jest próbą przybliżenia zawodowej biografii jednego z nieznanych międzywojennych architektów kolejowych.

Henryk Genello był architektem o dużych zasługach dla polskiej architektury kolejowej w okresie II RP. Obecnie jest to postać całkowicie zapomniana, brak jakiejkolwiek publikacji na jego temat. Próżno szukać informacji o tej postaci w słownikach biograficznych architektów polskich, literaturze naukowej i popularnej czy dokumentacji SARP-u. Ze względu na trudności związane z opracowaniem podstawowych nawet informacji dotyczących autorstwa jego realizacji, artykuł ten jest jedynie szkicem do portretu zapomnianego architekta kolejowego.

Henryk Genello urodził się 5 sierpnia 1872 r. w Tachańczy w guberni kijowskiej. Jego rodzicami byli Edward i Aleksandra z Papków, bratem był zapewne Mieczysław (1875-?) - lekarz kolejowy, a w okresie II RP ginekolog-położnik5. Genellowie byli rodziną włoską o uzdolnieniach artystycznych, która przybyła do Polski jeszcze przed rozbiorami. Początkowo rodowe nazwisko zapisywano prawidłowo jako Genelli, jednak rosyjscy urzędnicy zmienili jego pisownię na Geneli i Genello ${ }^{6}$. W ten sposób powstały trzy formy nazwiska rozgałęzionej rodziny zamieszkującej tereny Królestwa, Imperium Rosyjskiego i Galicji. Z jej polską częścią skoligacony był wybitny niemiecki grafik pochodzenia włoskiego Bonawentura Genelli (1798-1868)7 . Bliskim krewnym Henryka był także Stefan Geneli, właściciel Fabryki wódek, likierów

${ }^{2}$ A. Skalimowski, Z. Tucholski: Modernistyczne wiaty i przystanki kolejowe warszawskiego Węzła Kolejowego: o konieczności ochrony konserwatorskiej, „Ochrona Zabytków” nr 1-4/2010, s. 73-84.

${ }^{3}$ Problemy związane z określeniem autorstwa budynków kolejowych przypisywanych Romualdowi Millerowi napotkał architekt Michał Dudkowski, który przygotowuje rozprawę doktorską stanowiącą biografię zawodową tej postaci.

${ }^{4}$ Rosyjski okres pracy tego architekta, nie związany z kolejnictwem, opisano w artykule А.С. Евгений Шреттер - зодчий Серебряного века, „Архитектурное наследство” $\mathrm{nr}$ 47, 2007, s. 274-286.

${ }^{5}$ Absolwent medycyny z 1899 r., w latach 1908-14 lekarz kolejowy na stacji Kowel Kolei Południowo-Zachodnich. W II RP ginekolog-położnik w Zduńskiej Woli; por. Российский Медицинский список на 1908 год, s. 92; Россійскій Медицинскій Списокъ на 1914 годъ, http://personalhistory.ru/papers/rms1914.htm, dostęp 25 marzec 2017 r.; Urzędowy spis lekarzy uprawnionych do wykonywania praktyki lekarskiej, lekarzy dentystów, dyplomowanych farmaceutów oraz aptek w Rzeczypospolitej Polskiej, Warszawa 1931, s. 60.

${ }^{6}$ Relacja wnuka Jerzego Genello z 12 lutego $2017 \mathrm{r}$.

${ }^{7}$ Tamże. 
i win Stefan Geneli i S-ka w Warszawie, który zbudował pałacyk w Otrębusach ${ }^{8}$. Z rodziny tej pochodziła także Maria Geneli, malarka tworząca pod koniec XIX-wieku, specjalizująca się w sztuce sakralnej ${ }^{9}$.

Henryk Genello ukończył Szkołę Realną w Kijowie, w latach 1895-1906 studiował na Wydziale Architektury Politechniki Ryskiej. W tym okresie był członkiem Korporacji Akademickiej Welecja ${ }^{10}$. Pełnił później funkcję architekta w guberni mińskiej. Po rewolucji 1917 r. przyjechał do Polski i zamieszkał w Wilnie przy ul. Lubelskiej 5. 1 kwietnia 1920 r. objął stanowisko kierownika Działu Budynków Wydziału Drogowego Wileńskiej Dyrekcji Kolei Państwowych ${ }^{11} .19$ kwietnia 1921 r. ożenił się w Wilnie z Wandą z Łabanowskich, 18 czerwca 1922 r. urodził się tam ich syn Tadeusz ${ }^{12}$.

W okresie pracy na stanowisku kierownika Działu Budynków, projektował wspólnie z drugim architektem Wileńskiej DKP, inż. Hipolitem Hryncewiczem. W tym miejscu należy przedstawić biogram tego także całkowicie nieomal zapomnianego zasłużonego architekta kolejowego ${ }^{13}$. Architekt ten urodził się w $1876 \mathrm{r}$. na Kowieńszczyźnie, ukończył Gimnazjum w Szawlach. Po złożeniu egzaminu konkursowego wstąpił na Wydział Architektoniczny Cesarskiej Akademii Sztuk Pięknych w Petersburgu. Ukończył ją w 1908 r. z odznaczeniem w konkursie dyplomowym (Prix de Rome). W uznaniu wybitnych zdolności został delegowany przez akademię na dwa lata do Włoch. Do 1912 r. pracował jako architekt w Petersburgu przy budowie gmachów Banku Azowsko-Dońskiego i Syberyjskiego oraz prowadził samodzielne roboty budowlane. Brał udział w życiu kolonii polskiej w Petersburgu. W połowie 1912 r. przeniósł się do Moskwy, gdzie - reprezentując wybitnego rosyjskiego architekta prof. Aleksandra Pomierancewa - prowadził roboty przy budowie Soboru Aleksandra Newskiego w Moskwie ${ }^{14}$.

W 1919 r. powrócił z Rosji bolszewickiej do Wilna, gdzie w czasie wojny 1920 r. pracował w budownictwie wojskowym. W listopadzie 1921 r. został zatrudniony jako architekt na stanowisku referenta w Dziale Budynków Wydziału Drogowego

${ }^{8}$ Ibidem.

${ }^{9}$ PAN Instytut Sztuki, Słownik artystów polskich i obcych w Polsce działających, malarze rzeźbiarze graficy, t. II. Warszawa 1975, 303-304.

10 http://www.archiwumkorporacyine.pl/index.php/muzeum-korporacyine/ryga/k-welecja/ Archiwum Korporacyjne. Archiwum i Muzeum Polskich Korporacji Akademickich. Rok założenia 1974 - 1988 - 2001.

${ }^{11}$ Archiwum Zakładowe Ministerstwa Infrastruktury (dalej AZMI), sygn. 98/1955, Akta osobowe inż. Henryka Genello, Kwestionariusz Henryka Genello, 16 lipca 1945 r., k. 1.

${ }^{12}$ Tamże; Tadeusz Genello (1922-1991), inżynier telekomunikacji, absolwent Wydziału Elektrycznego Politechniki Łódzkiej. Pracował w Ministerstwie Łączności oraz Instytucie Łączności. W 1963 r. wyjechał do Ghany jako ekspert d.s. telekomunikacji i tworzył sieć telefoniczną w tym kraju, potem przez dwa lata tworzył sieć telefoniczną w Nigerii; relacja Jerzego Genello z 19 maja 2017 r.

${ }^{13}$ Lakoniczny kilkuzdaniowy biogram Hipolita Hryncewicza znajduje się w Encyklopedii Ziemi Wileńskiej, Wileńskim Słowniku Biograficznym, Bydgoszcz 2002, s. 108.

${ }^{14}$ „Słowo”, 18 X 1933 r., Marian Kulesza, Wspomnienie pośmiertne ś.p. Hipolit Hryncewicz, s. 3. 
Wileńskiej Dyrekcji Kolei Państwowych w Wilnie (później Dyrekcji Okręgowej Kolei Państwowych) i rozpoczął prace przy odbudowie zniszczonych podczas wojny budynków kolejowych. Hryncewicz od lat 20. XX w. wykładał jako kontraktowy lektor rysunek architektoniczny na Wydziale Sztuk Pięknych Uniwersytetu Stefana Batorego w Wilnie ${ }^{15}$. Był członkiem Koła Wileńskiego Związku Polskich Inżynierów Kolejowych. Zmarł nagle 15 października 1934 r. w Wilnie i został pochowany na wileńskim Cmentarzu na Rossie ${ }^{16}$.

Sieć kolejowa na terenie późniejszej Dyrekcji Wileńskiej była w znacznym stopniu zniszczona podczas I wojny światowej oraz wojny polsko-bolszewickiej. W toku walk oraz planowego niszczenia infrastruktury podczas wycofania walczących wojsk przestało istnieć wiele dworców i innych budynków kolejowych. W kierowanym przez Genello Dziale Budynków, oprócz obu architektów, było zatrudnionych jeszcze około dziesięciu niższych urzędników. Do zadań tego działu należała odbudowa i budowa nowych budynków kolejowych na terenie sieci kolejowej całej dyrekcji. Sporządzanie ich projektów i prowadzenie prac należało do obowiązków tylko dwóch architektów.

Budowa reprezentacyjnych dworców na obszarze szczególnie silnie zniszczonym podczas obu wojen miała znaczenie utylitarne. Nie mniej ważny był jednak narodowy i państwowotwórczy charakter architektury zacierającej w warstwie stylistycznej symbolikę administracyjnej rusyfikacji i germanizacji przestrzeni publicznej. Inżynier Juliusz Dzierżanowski, co prawda już w apogeum modernizmu, tak pisał o potrzebie narodowego stylu w architekturze:

Każdy naród, rozwijając się samodzielnie, odczuwa potrzebę zaznaczenia swej odrębności. Dążenie to, jako odruch podświadomy, wyraża się i utrwala przede wszystkim w dziełach sztuki, a więc i w architekturze [...] Zachowanie cech tej odrębności powinno być zadaniem naszych architektów, nie tylko w budowlach monumentalnych użyteczności publicznej i gmachach reprezentacyjnych, lecz w ogóle we wszystkich budynkach, wznoszonych na ziemiach polskich ${ }^{17}$.

Publiczna architektura narodowa miała szczególne znaczenie na Kresach, w warstwie estetycznej i symbolicznej repolonizowała te tereny po okresie zaborów, gdy ziemie te miały być w pierwszej kolejności zrusyfikowane i połączone z Imperium. Dworce, podobnie jak inne budynki państwowe, czy użyteczności publicznej, wedle zamysłu twórców miały być emanacją polskości na tych wieloetnicznych obszarach:

[...] pod względem architektury większość tych dworców oparta jest na motywach polskiego baroku [...] Starania Dyrekcji w tym kierunku dały bardzo dobre rezultaty, gdyż dzięki temu, w powstających z gruzów zniszczenia wojennego naszych woje-

15 „Inżynier Kolejowy” 1934, nr 1, s. 30, nekrolog.

16 „Słowo”, nr 284, 17 X 1933 r., s. 35, nekrolog.

17 J. Dzierżanowski: Dworzec kolejowy w Zułówie, „Kolejowy Przegląd Techniczny” 1935, nr 7 , s. 1. 
wództw wschodnich, w znacznym stopniu starty został pokost rosyjski, a natomiast kultura polska wycisnęła tam już bardzo głębokie ślady ${ }^{18}$.

W pracy Dziesięciolecie Polskich Kolei Państwowych 1918-1928 tak pisano o polonizacji kolejowej architekturze zaborczej na sieci PKP:

[...] budownictwo kolejowe pozbyło się odrazu śladów niewoli moskiewskiej i austrjackiej, które, gdyby nie to, dłuższy czas jeszcze szpeciłyby krajobraz polski w postaci brzydkich i obcych naszej kulturze typowych budowli kolejowych moskiewskich i austrjackich ${ }^{19}$.

Szerszy kontekst i przyczynę popularności na Kresach stylu narodowego scharakteryzował w celny sposób w swej pracy „Kresy nowoczesne” Michał Pszczółkowski:

Na terenach województw wschodnich, szczególnie w pierwszych latach powojennych, stylistyka narodowa była ważnym narzędziem polonizacji Kresów [...] Podatne na wpływy komunizmu mniejszości narodowe, głoszące opinie o tymczasowości władzy polskiej, należało przekonać do trwałej obecności Polski na tych terenach, miejscowym Polakom służyć »ku pokrzepieniu serc«, zaś przybywających na Kresy urzędników i wojskowych osadników przekonywać, że nie są na zesłaniu i mogą z tymi ziemiami związać swoją przyszłość. Okoliczności te powodowały, że nurt tradycjonalny cieszył się na tutejszym gruncie wielką popularnością ${ }^{20}$.

W celu odbudowy, przebudowy i budowy dworców oraz innych budynków kolejowych w stylu narodowym na terenie Dyrekcji Wileńskiej powołano podporządkowany istniejącemu w DKP Wilno Działowi Budynków - zespół architektów. W jego skład wszedł zapewne Henryk Genello, Hipolit Hryncewicz oraz Tadeusz Rostworowski ${ }^{21}$. W latach 20. XX w. Dyrekcja Wileńska zbudowała na swym terenie niespełna pięćdziesiąt dworców kolejowych oraz dużą liczbę innych budynków ${ }^{22}$. Architekci wchodzący w skład zespołu, samodzielnie lub wspólnie, zaprojektowali w tym okresie w polskim stylu narodowym wiele dworców. Były to obiekty realizowane według kilku powtarzalnych projektów. Hryncewicz był między innymi autorem budowy i odbudowy dworców wzniesionych w tym stylu na stacjach węzłowych linii Białystok - Brześć n/Bugiem - Stołpce, a także na innych odcinkach linii Dyrekcji Wileńskiej. Według jego projektu zrealizowano między innymi dworce: Brześć n/ Bugiem (1930 r.), Wołkowysk Miasto, Słonim (1922 r.) i Pińsk. Nie wiadomo jednak,

${ }^{18} \mathrm{~J}$. Wołka n ow ski : Otwarcie nowego dworca na st. Stołpce, „Inżynier Kolejowy” 1926, nr 11, s. 324.

${ }^{19}$ Dziesięciolecie Polskich Kolei Państwowych 1918-1928, Warszawa 1928 s., s. 85; cytat za: M. P s z c zół ko ws ki : Kresy nowoczesne. Architektura na ziemiach wschodnich II Rzeczypospolitej 1921-1939, Łódź 2016, s. 35.

${ }^{20}$ M. P s z c zółkowski: s. 34.

${ }^{21}$ Tadeusz Rostworowski (1860-1928), architekt wileński.

${ }^{22}$ P. J. Ja m s ki : Pocztówki z Kresów przedwojennej Polski, Warszawa 2012, s. 51. 
czy część z nich nie powstała we współpracy Hryncewicza i Genello. Brak źródeł, a przede wszystkim oryginalnych projektów, nie pozwala dziś na przyporządkowanie ich autorstwa lub określenie autorstwa wspólnego.

Michał Pszczółkowski w swej pracy Kresy Nowoczesne analizował również kresową architekturę kolejową, przyporządkowując poszczególne dworce do powtarzalnych projektów:

Obiekty te przebudowywano, nadając im cechy architektury narodowej. W ten sposób na przykład dworcom linii Siedlce - Wołkowysk - Zahacie (m.in. Różanka, Juraciszki, Bohdanów, Kniahinin), utrzymanym w uproszczonych formach bizantyjsko-ruskich, dodano dachy mansardowe z lukarnami i szczyty zamknięte łukiem segmentowym. Formy tradycjonalne stosowano ponadto w nowych realizacjach, w tym częstych na Kresach projektach powtarzalnych. Można tu wymienić model zastosowany na Wileńszczyźnie - w Jaszunach, Olkiennikach, Rudziszkach, Bastunach i Bieniakoniach, następnie model wykorzystany w Leśnej koło Baranowicz i Orańczycach, kolejne w Werbkowicach i Kostopolu oraz Nowojelni i Podbrodziu ${ }^{23}$.

Wszystkie wymienione powtarzalne typy dworców musiały być autorstwa Genello i Hryncewicza. Niezwykle istotne byłoby przeprowadzenie badań w zakresie kresowej architektury kolejowej. Kwerendy w archiwach litewskich i białoruskich zapewne w pełni wyjaśniłyby autorstwo tych projektów.

Celnym opisem polskiego stylu narodowego w architekturze kolejowej Kresów jest list z 9 grudnia 1937 r., pióra anonimowego inżyniera kolejowego do córki, zatytułowany „Dworki II Rzeczpospolitej”, czytamy w nim:

Moja ulubiona stacja kolejowa w wileńskiej DOKP to Bastuny. Budyneczek - maleństwo, jak dworek kresowy - nieco przypomina budowlę skarbczyka Wahlów w Iszczołnie [...] Stacja w Bastunach jest jedną z prawie pięćdziesięciu nowo wzniesionych w tym okręgu; większość egzystujących przed wojną zniszczonych zostało znacznie i lepiej było na nowo budować, niż naprawiać wcześniejsze. Ważne również, że obecny ich wygląd odpowiada zmienionym warunkom politycznym, współgra z polskim duchem i wtapia się architekturą w krajobraz Wileńszczyzny i ziemi nowogródzkiej. Tak pomyślane zabudowania stacyjne odzyskiwać mają krajobraz ojczysty. W prostych formach, jasnych tynkach, nowoczesnej funkcjonalności - są miejscem propagandy sztuki i siły naszego Państwa. Prawie wszystkie zaprojektowane przez Panów Rostworowskiego i Hryniewicza ${ }^{24}$, nawiązują do drewnianych dworków polskich, chyba po to, by każdy korzystający z usług PKP podróżny czuł się jak szlachcic. Taki wybór miał podłoże w idei odwrócenia się od dwarca, jak mówią czasami jeszcze na ziemiach wschodnich, używając rosyjskiego słowa oznaczającego »pałac«. Carowie chcieli, by główne stacje kolejowe były jak pałace imperialnej chwały. Nasi architekci obecnie wolą jednak, by dworzec kojarzył się raczej z polskim dworkiem. Stacja to nic

\footnotetext{
${ }^{23}$ M. P s z c zółk o w ski : s. 35.

${ }^{24}$ Błędny zapis nazwiska, powinno być: Hryncewicza.
} 
innego przecież, jak pełen polskiej gościnności dwór, gdzie zatrzymać się można bez uprzedzenia, zjeść i odpocząć w podróży25.

Szczególnie okazałą i wartościową realizacją obu architektów był powstały w 1926 r. duży, reprezentacyjny dworzec na granicznej stacji Stołpce:

Budowa tego dworca, można powiedzieć bez przesady, wykonana została w rekordowym czasie nie tylko dla naszych stosunków powojennych, lecz nawet w odniesieniu do okresu przedwojennego. Projekt dworca wykonany został w ciągu tygodnia, przez architektów Dyrekcji Wileńskiej pp. H. Genella i Hryncewicza ${ }^{26}$.

Czerpał on inspirację z wcześniejszych realizacji - jego tradycyjny program i układ wnętrz był charakterystyczny dla XIX-wiecznej architektury kolejowej. Dworzec był nakryty stosunkowo wysokim dachem charakterystycznym dla realizacji w stylu narodowym. Dla tej architektury typowa była również symetryczna osiowość i narastanie bryły. Oszczędne detale architektoniczne i układ części okien w elewacji nosiły już jednak cechy funkcjonalizmu. Architektura budynku była formą przejściową pomiędzy stylem narodowym, a modernizmem w polskim kolejnictwie. Michał Pszczółkowski określa architekturę tego dworca, a także budynków dworcowych w Lidzie i Zbąszyniu, mianem klasycyzmu zmodernizowanego ${ }^{27}$.

We wnętrzu dworca zlokalizowano halę ogólną, poczekalnię III kl., pomieszczenie bagażu, pocztowe i telegrafu, poczekalnie oraz bufet I i II kl., szatnię męską i damską, lokal fryzjera i szalety, salę rewizyjną, lokale dla służby celnej, policji i służby ruchu PKP. Dworzec został zrealizowany w ciągu 115 dni roboczych, a roboty prowadziła firma budowlana J. Pawlikowskiego pod kierownictwem Wileńskiej Dyrekcji Kolei Państwowych. Fachowców do prac budowlanych sprowadzono z Warszawy, Brześcia, Łodzi i Poznańskiego. Do budowy dworca użyto cegły z Poznańskiego, stolarkę i roboty ślusarskie wykonano w Warszawie. Prace budowlane ukończono 30 września 1926 r. Po oddaniu dworca na łamach czasopisma „Inżynier Kolejowy” ukazał się jego lakoniczny opis ${ }^{28}$. Niewątpliwie była to jedna z lepszych realizacji polskiej architektury kolejowej na Kresach w II RP.

Podobną przejściową formę posiadał zrealizowany w tym samym roku według projektu architekta Romualda Millera dworzec kolejowy w Gdyni:

Projekt ten z jednej strony kończy etap architektury narodowej, z drugiej zaś, jako przykład odmiennego myślenia o architekturze, otwiera w praktyce Millera nowy modernistyczny okres. Od tego czasu w realizacjach architekta trudno znaleźć tak dosłowne, wyrwane z kontekstu cytaty z architektury » polskiej«, historycznej ${ }^{29}$.

\footnotetext{
${ }^{25}$ P. J. Jam ski : Pocztówki..., s. 51.

${ }^{26} \mathrm{~J}$. Wołkan owski: s. 324.

27 M. Pszczółkowski: Architektura użyteczności publicznej II Rzeczypospolitej 1918-1939. Funkcja, Łódź 2015, s. 283.

${ }^{28} \mathrm{~J}$. Wołkan owski: s. 324.

${ }^{29}$ K. Ta bak: s. 47.
} 


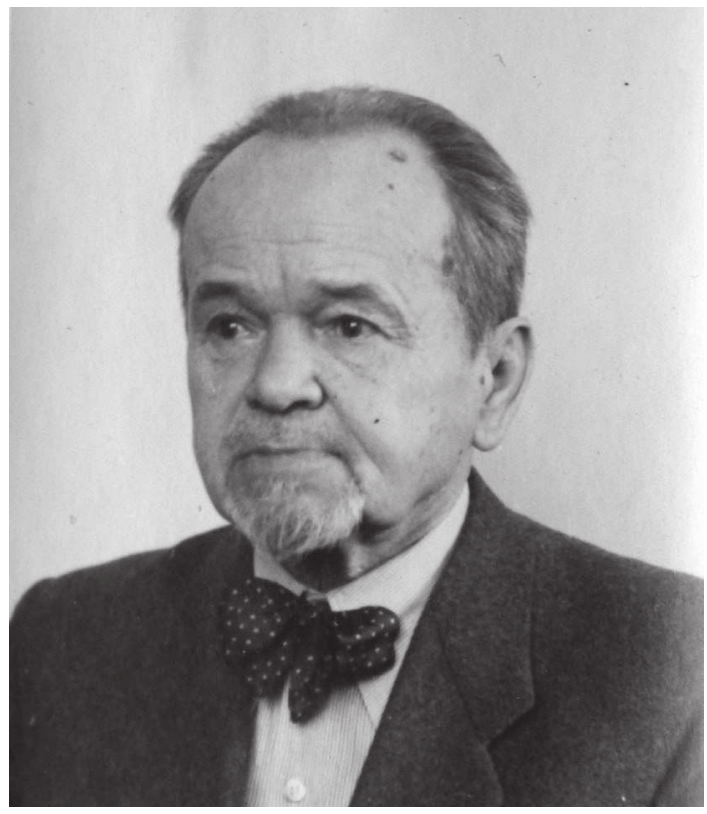

Il. 1 inż. Henryk Genello, Fotografia z 1947 r. Archiwum Zakładowe Ministerstwa Infrastruktury

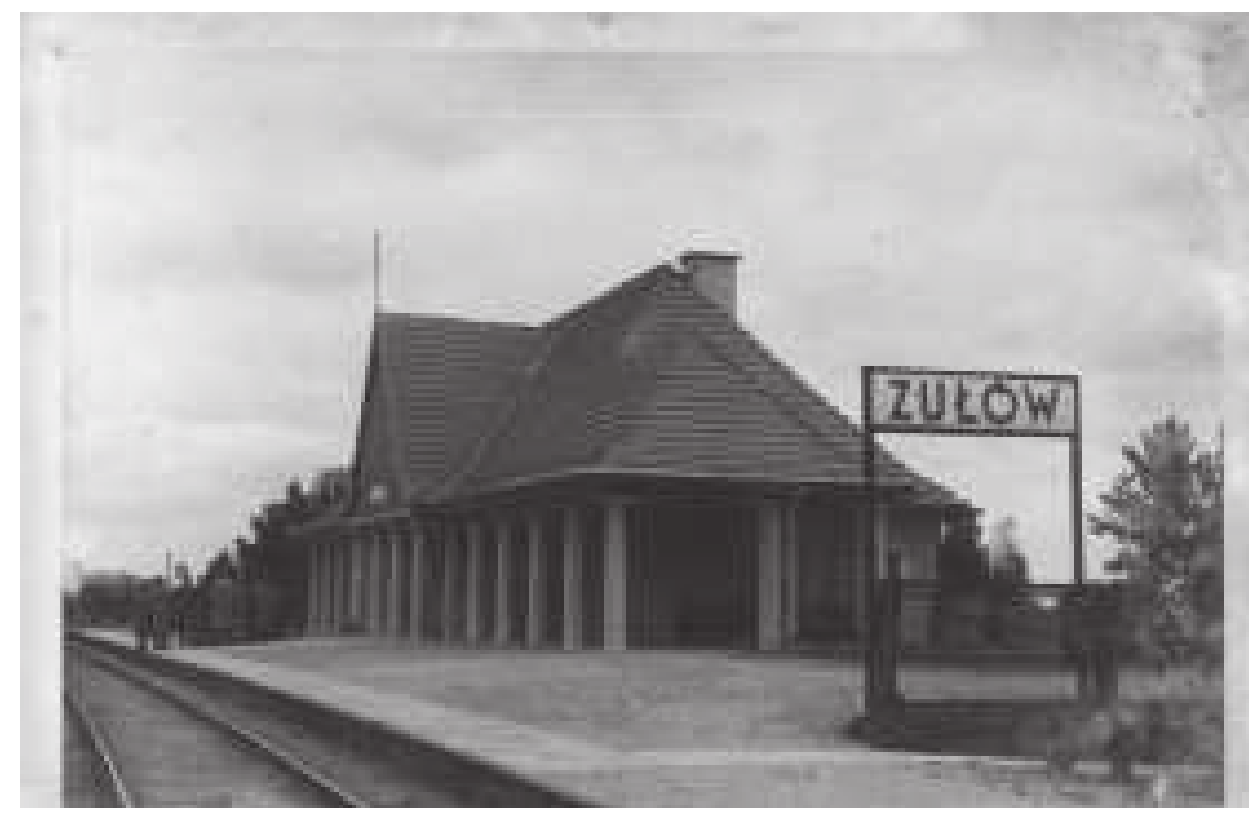

Il. 2. Dworzec PKP w Zułowie, źródło: Internet 


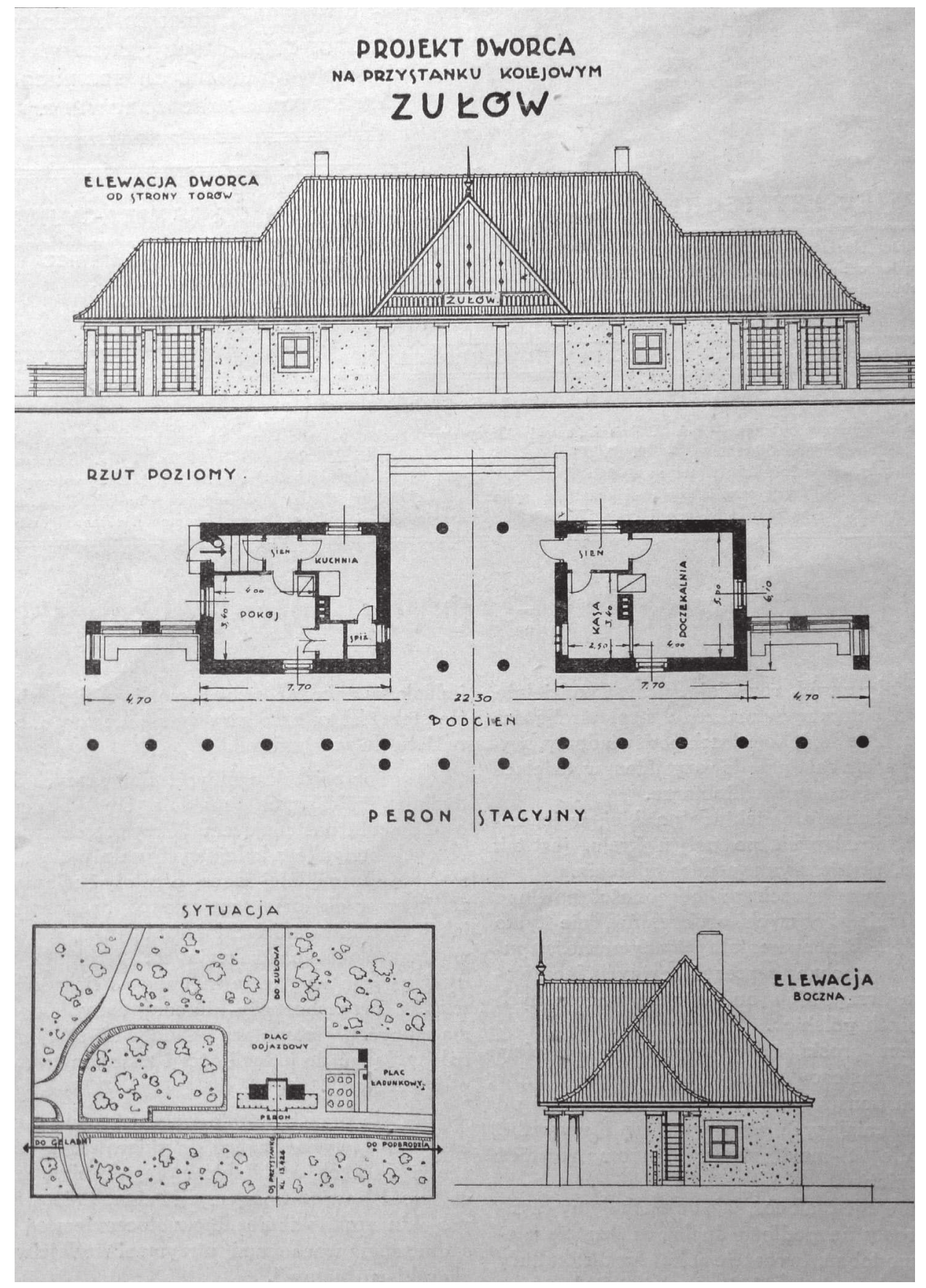

Ryc. 3. Projekt dworca w Zułowie, „Kolejowy Przegląd Techniczny” 1935 r., nr 7, s. 2 


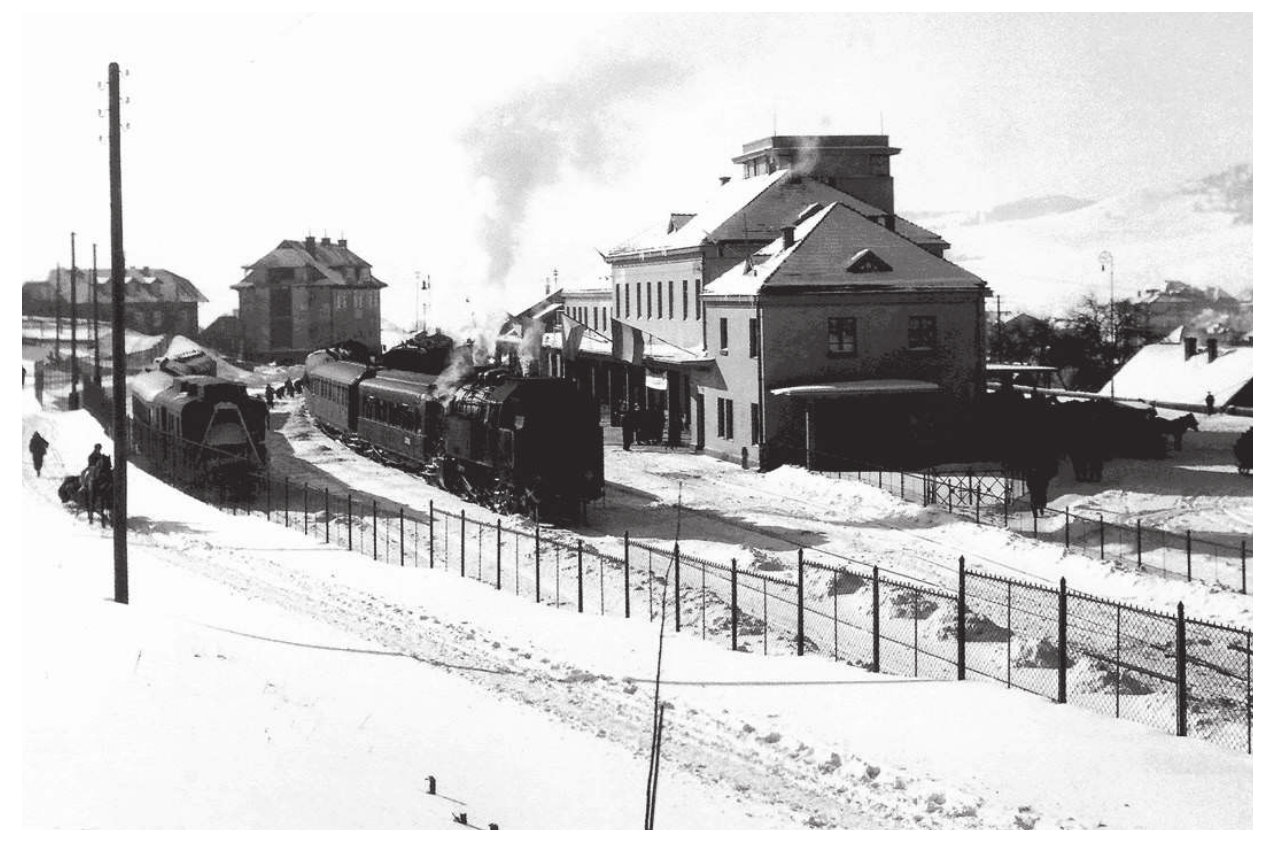

Il. 4 Dworzec PKP w Krynicy l. 30. XX w,, źródło: Internet

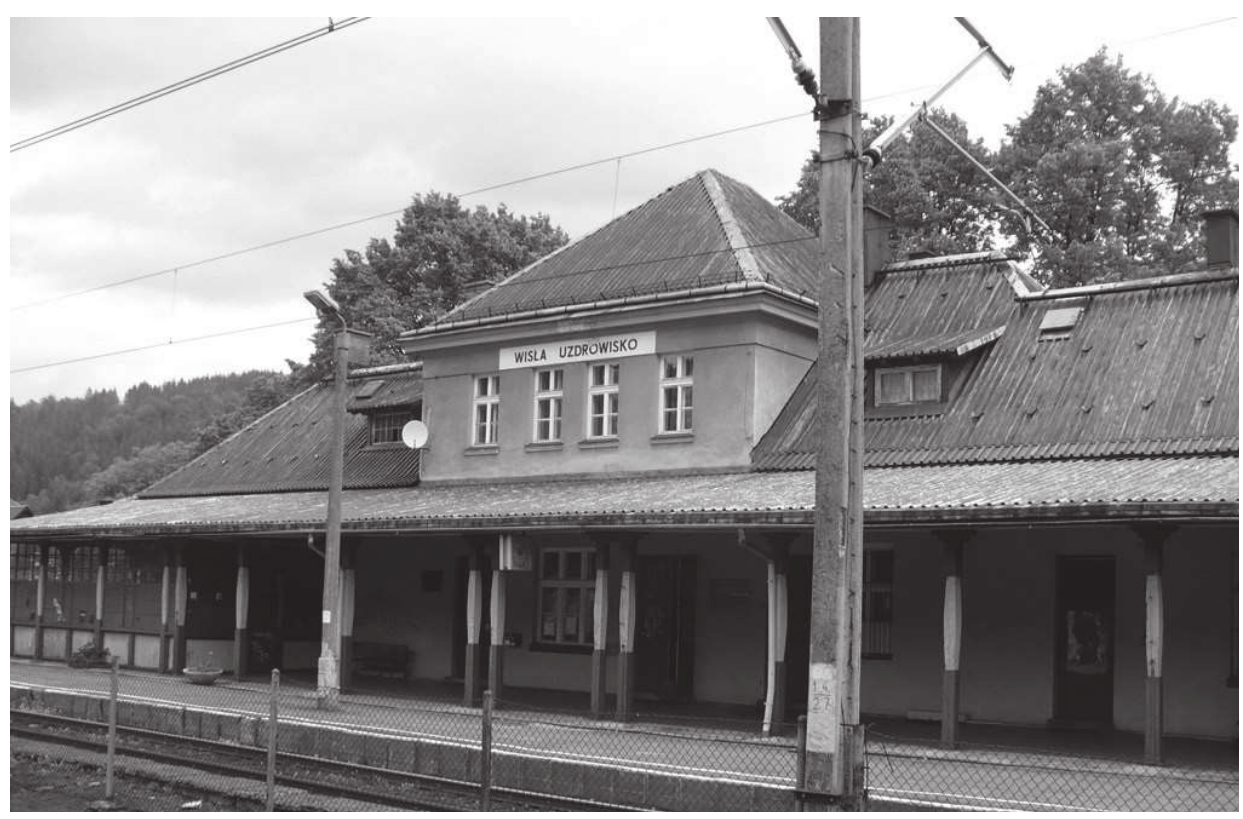

Il. 5. Stacja kolejowa Wisła-Uzdrowisko, fotografia współczesna. 


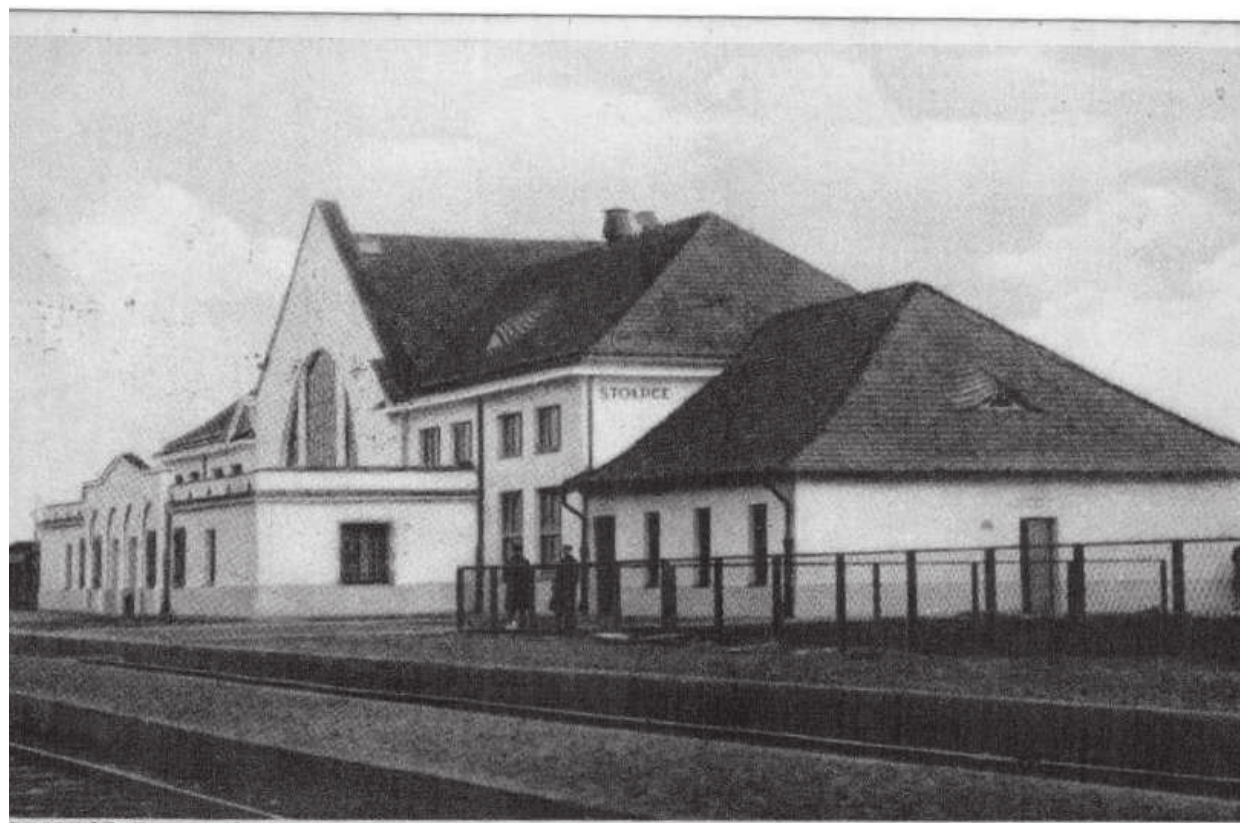

Il. 5 Dworzec kolejowy w Stołpcach, fot. S. Utlewski, pocztówka z lat 30. XX w.

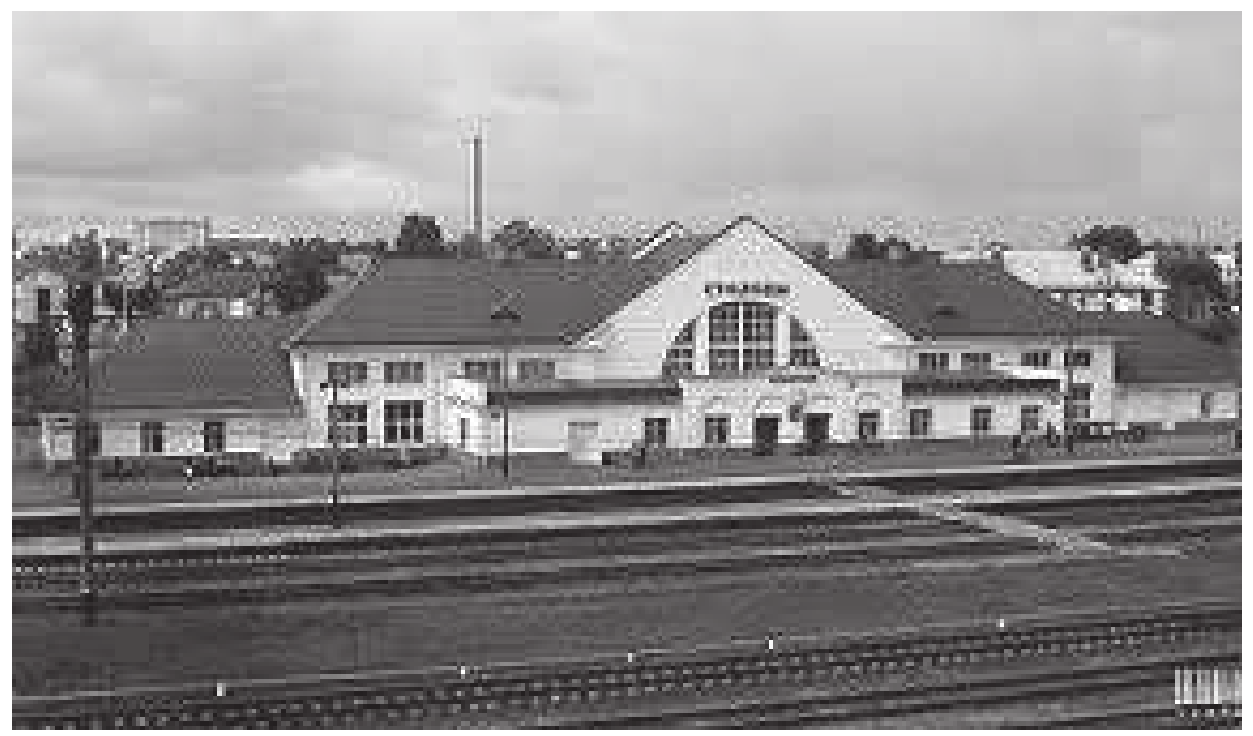

Il. 6. Dworzec kolejowy w Stołpcach, fot. współczesna, źródło: Internet 
Dworzec krytykowany za konserwatywną formę posiadał już w stosunku do wcześniejszych kolejowych projektów typowych Millera wyraźne cechy modernizmu. Stacja Stołpce zrealizowana przez Genella i Hryncewicza była niewątpliwie znacznie bardziej modernistyczną realizacją od dworca w Gdyni i niewątpliwie posiada znaczenie przełomowe dla przejścia od stylu narodowego do modernizmu w polskiej architekturze kolejowej II Rzeczypospolitej. Ewolucja w kierunku modernizmu była spowolniona przez wytyczne Wydziałów Architektonicznych przy poszczególnych Dyrekcjach Kolei Państwowych, które bardzo długo stosowały w założeniach projektowych podział na klasy dworców funkcjonujący na dawnych kolejach imperium rosyjskiego (wraz z przyporządkowanym im układem funkcjonalnym).

Genello był również autorem co najmniej dwóch projektów nie związanych z kolejnictwem. W 1926 r. zaprojektował, w stylu inspirowanym architekturą zakopiańską, nowy, drewniany, reprezentacyjny budynek przystani Towarzystwa Wioślarskiego w Wilnie, którego był członkiem ${ }^{30}$. Obiekt był dostosowany do swej funkcji - wkomponowano go w stok nadrzecznej skarpy. Przy platformie pomostu przystani, do której cumowały łodzie, przewidziano w centralnej części dwa lustrzane biegi schodów ze wspólnym spocznikiem. Na III kondygnacji umieszczono zadaszony balkon biegnący przez całą szerokość elewacji. Budynek zaprojektowano jako przekryty dachem naczółkowym (prawdopodobnie pokrytym gontem). Od strony rzeki w dachu przewidziano symetryczną facjatę z dwoma dekoracyjnymi szczytami i oknem termalnym. W 1929 r., według projektu Genello z 1927 r., zbudowano niewielki kościół pw. św. Anny w Jaszunach, inspirowany architekturą kresową ${ }^{31}$.

W tym samym roku Genello w warszawskiej siedzibie spółki „Endler \& Messing”, przedstawicielstwie Forda w Polsce, wykonał projekt „domu mieszkalnego z biurami i magazynami" z przeznaczeniem na siedzibę domu handlowego tej firmy w Gdy$\mathrm{ni}^{32}$. W latach 1928-1929, według tego projektu, zbudowano przy ul. Świętojańskiej 56 w Gdyni czteropiętrową kamienicę. Nosiła ona cechy wczesnego funkcjonalizmu, jej elewacja miała bardzo oszczędny detal: „Pierwsze piętro tej budowli miało obszerne pomieszczenia biurowe, a wyżej były mieszkania z trzema pionami balkonów i oknami ujętymi w poziome pasy" 33 .

1 kwietnia 1928 r. Genello został przeniesiony na stanowisko starszego referendarza Dyrekcji Kolei Państwowych w Warszawie i delegowany do Wydziału

${ }^{30}$ Przystań siedziba Towarzystwa Wioślarskiego w Wilnie, „Sport Wodny” 1926, nr 5, s. 59; Nie wiadomo, czy projekt ten został zrealizowany.

${ }^{31}$ G. Ru s z c zy k: Drewniane kościoły w Polsce 1918-1939. Tradycja i nowoczesność, Warszawa 2001, s. 229.

${ }^{32}$ M. S oł ty s i k: Na styku dwóch epok. Architektura gdyńskich kamienic okresu międzywojennego, Gdynia 2003, s. 135.

${ }^{33}$ Tamże; W 1930 r. kamienica ta została sprzedana na przymusowej licytacji Antoniemu Jaworowiczowi. 
Budynków Departamentu Utrzymania i Budowy Kolei Ministerstwa Komunikacji ${ }^{34}$. Wydział ten był kierowany przez jego przyjaciela i również korporanta Welecji inż. arch. Józefa Wołkanowskiego ${ }^{35}$. Prawdopodobnie dzięki jego staraniom zdolny architekt został sprowadzony do Warszawy. Po przybyciu do stolicy wraz z rodziną zamieszkał w okazałym domu urzędników Ministerstwa Komunikacji przy ul. Targowej 70. W 1932 r. mianowano go radcą ministerialnym ${ }^{36}$ i zapewne zatrudniono wówczas na etacie w Wydziale Budynków Departamentu Utrzymania i Budowy Kolei Ministerstwa Komunikacjii ${ }^{37}$. Mniej więcej od tego czasu, po odwołaniu Wołkanowskiego, pomimo vacatu na stanowisku naczelnika Genello kierował de facto Wydziałem Budynków, kształtując architekturę kolejową II RP ${ }^{38}$.

W trakcie pracy na stanowisku ministerialnym, Genello nadal był czynnym zawodowo architektem kolejowym. Od lat 30. XX w. jego projekty stały się modernistyczne, były podporządkowane ówczesnemu etatystycznemu funkcjonalizmowi. Architekci implementując wówczas nowy prąd w państwowej architekturze dwudziestolecia musieli przystosować się do zmiany formy. Dostosowanie się do ówczesnego kanonu architektonicznego najlepiej oddaje twórczość Romualda Millera ${ }^{39}$.

Według rodzinnego przekazu Genello zaprojektował również budynki stacyjne na zbudowanej w latach 1928-33 „turystycznej” linii kolejowej II RP Ustroń Wisła-Głębce ${ }^{40}$. Wzniesiono je na następujących stacjach: Polana, otwarta 15 marca 1928 r. (od 1953 r. Ustroń Polana); Obłaziec, otwarta 10 lipca 1929 r. (od 1957 r. Wisła Obłaziec), Wisła, otwarta 10 lipca 1929 r. (od 1934 r. Wisła-Uzdrowisko), Dziechcinka, otwarta 11 września 1933 r. (od 1957 r. Wisła-Dziechcinka), Głębiec, otwarta 11 września 1933 r. (1934-36 Głębce, 1937-39 Wisła-Głębce, po 1945 r. Wisła-Głębce $)^{41}$. Kilkuletni odstęp czasu między otwarciem kolejnych stacji i budową dworców wynikał z etapowej realizacji tej niezwykle trudnej terenowo górskiej linii.

34 „Inżynier Kolejowy” 1928, nr 8, Mianowania, s. 255; „Rocznik Kolejowy” 1930, s. 8.

${ }^{35}$ Józef Wołkanowski (1880-1963), architekt. Studiował w Instytucie Politechnicznym w Warszawie, następnie ukończył Wydział Architektury Politechniki Ryskiej (1913). Członek Korporacji Akademickiej Welecja. Po 1918 r. naczelnik Wydziału Architektury Ministerstwa Kolei Żelaznych. Następnie dyrektor DKP Stanisławów, a po jej likwidacji DOKP Kraków. W połowie lat 30. XX w. dyrektor Centralnego Biura Zakupów MK, organizator Muzeum Kolejowego/Komunikacji. W okresie powojennym zaangażowany w odbudowę Muzeum Komunikacji oraz organizację Muzeum Techniki NOT.

${ }^{36}$ Ruch służbowy w Ministerstwie Komunikacji i Dyrekcjach Okręgowych Kolei Państwowych (Dz. Urz. nr 12 i 17); „Inżynier Kolejowy” 1932, nr 9, s. 214.

${ }^{37}$ AZMI, sygn. 98/1955, Akta osobowe inż. Henryka Genello, Kwestionariusz Henryka Genello, 16 VII 1945 r., k. 1.

38 „Rocznik Komunikacyjny” 1933/34, s. 8.

${ }^{39} \mathrm{~K}$. Ta ba k: Romualda Millera droga do modernizmu. Od dworca kolejowego w Gdyni po warszawskie realizacje lat 30. XX w.; [w:] Trwałość? Użyteczność? Piękno? Architektura dwudziestego wieku w Polsce, Wrocław 2011, s. 46-47.

${ }^{40}$ Relacja wnuka Jerzego Genello z 12 lutego 2017 r.

${ }^{41}$ Kolej Śląska Cieszyńskiego, http://kolejcieszyn.pl/191.php?s=wislaob, dostęp 28032017 r. 
Forma architektury budynków stacyjnych, zaprojektowanych w oszczędnym stylu „narodowym”, a także jej nawiązania do motywów zakopiańskich mogą potwierdzać autorstwo Henryka Genello. Na stacji Obłaziec i Dziechcinka zrealizowano niewielkie drewniane stacje konstrukcji słupowej w stylu zakopiańskim, co wynikało zapewne z oszczędności, ale w warstwie symbolicznej mogło być także konsekwencją lokalnych inspiracji architekta. Należy jednak podkreślić, iż autor niniejszego artykułu nie dotarł do żadnych źródeł dokumentalnych potwierdzających to autorstwo. Projektu Genello są zapewne również i inne obiekty zrealizowane na tej linii - nastawnie, magazyny oraz szalety, utrzymane w stylu budynków dworcowych wznoszonych na poszczególnych stacjach.

W 1929 r., wspólnie z malarzem Maciejem Nehringiem² ${ }^{42}$, doradcą artystycznym Ministerstwa Komunikacji, Genello zaprojektował dekorację wewnątrz reprezentacyjnego pawilonu Ministerstwa Komunikacji na Powszechnej Wystawie Krajowej w Poznaniu ${ }^{43}$. Projektantem tego pawilonu był architekt Wacław Podlewski, współpracował z nim syn Wacław, który był także współautorem grafiki wewnętrznej ekspozycji ${ }^{44}$.

W 1933 r., według projektu Genello, dokonano rozbudowy dawnego dworca z czasów monarchii austro-węgierskiej na stacji w Krynicy. Parterową część dawnego dworca austriackiego, wkomponowano w nowe założenie i przystosowano do funkcji administracyjnej. Zespół otrzymał modernistyczną formę oraz nowy, symetryczny układ zabudowy. Dobudowano do niego dominującą nad całym zespołem wieżę, łączącą dawny budynek stacyjny z nowym skrzydłem południowym. W dolnej części wieży powstał, wsparty na słupie, narożny ganek z wejściem prowadzącym do hali dworcowej, na jej ostatniej kondygnacji umieszczono okna narożne. Wieżę i oba skrzydła zwieńczono prostym gzymsem koronującym. Od strony północnej zrealizowano dwukondygnacyjny budynek nakryty dachem namiotowym. W dobudowanej południowej części dworca zlokalizowano poczekalnię i kasy biletowe. Budynek otrzymał podłużne otwory okienne doświetlające wnętrze. Od strony torów wzdłuż dworca zbudowano wiatę peronową konstrukcji żelbetowej. Ukończenie obiektu planowano w lecie 1933 r., na ten cel przeznaczono 400000 zł. Inwestycję zrealizowano na wniosek Ministerstwa Komunikacji, które zaplanowało przystosowanie stacji i dworca do intensywnego, całorocznego ruchu turystycznego ${ }^{45}$. Oszczędna forma architektoniczna obiektu wynikała zapewne z konieczności szybkiej rozbudowy.

${ }^{42}$ Maciej Nehring (1901-1977), malarz, grafik i wybitny akwarelista. Ukończył Państwową Szkołę Przemysłu Artystycznego w Bydgoszczy oraz Szkołę Sztuk Pięknych w Warszawie. Założyciel i prezes „Grupy Akwarelistów”. W latach 1933-39 kierownik Pracowni Akwareli i Grafiki Użytkowej ASP w Warszawie.

${ }^{43}$ S. Wa sile ws ki : Pokaz Ministerstwa Komunikacji na Powszechnej Wystawie Krajowej w Poznaniu, „Inżynier Kolejowy” 1929, nr 7, s. 205.

${ }^{44} \mathrm{H}$. B i l ew i cz: Włodzimierz Podlewski: architektura i sztuka. W roku jubileuszu stulecia urodzin, Gdańsk 2008 r., s. 7.

${ }^{45}$ Nowy dworzec kolejowy, „Goniec Śląski” nr 13, 17 styczeń 1933 r., s. 5. 
W połowie lat 30. XX w. powstała koncepcja utworzenia tzw. Rezerwatu Zułowskiego w Zułowie w formie memoratywnego założenia parkowego reliktów fundamentów dworu i zabudowań majątku Piłsudskich. Jego centralnym punktem miały stać się zakonserwowane i częściowo odtworzone fundamenty spalonego dworu, w którym urodził się późniejszy marszałek. Rezerwat powstał według zwycięskiego projektu konkursowego z 1935 r. inż. arch. Romualda Gutta i inżyniera ogrodnictwa Aliny Scholtz ${ }^{46}$. Założenie miało stać się jednym z najważniejszych miejsc pamięci marszałka:

„W obrębie tak zrekonstruowanego »planu« kulminacyjnym punktem była mensa ołtarzowa i ściana erekcyjna (z kamienia narzutowego z okolic Antesor), na tle której - z "pokoju/sypialni«, w którym przyszedł na świat Marszałek - wyrastał złotolistny dąb $\mathrm{b}^{47}$.

Rezerwat Zułowski stanowił jedną z najlepszych w II RP realizacji parkowoogrodowych. W ten sposób jego istotę opisała Marta Leśniakowska:

W Zułowie ład sztuki i historii połączył się w sposób wzorcowy z ładem natury. Z formalnego punktu widzenia mamy tu do czynienia z nową, konserwatorsko-kulturową redefinicją proto- i romantycznej tradycji ogrodowej, gdzie określone idee i wrażenia stymulowane są przy pomocy imitowanych krajobrazów, oraz psychologizmu wynikającego ze związku natury i architektury ${ }^{48}$.

W 1937 r., z udziałem prezydenta Ignacego Mościckiego i wdowy po marszałku, dokonano uroczystego otwarcia parku-rezerwatu. W 1938 r. tak opisywał znaczenie rezerwatu niedoszły malarz marszałek Edward Śmigły-Rydz:

Ta architektura [...] - jedynie wówczas godna jest poparcia władz , gdy powoduje »dławiące w gardle wzruszenie« i gdy odrodzić się w niej może »duch polski«, zacierany, czy wręcz unicestwiany w kosmopolitycznych, likwidatorskich pomysłach lewicowej awangardy ${ }^{49}$.

Po otwarciu rezerwatu zwiększył się ruch turystyczny do Zułowa, wiele wycieczek instytucjonalnych, szkolnych, harcerskich, wojskowych, ale także turystów

${ }^{46}$ Alina Scholtz (1908-1996), wybitny polski architekt zieleni. W 1928 r. ukończyła Wydział Ogrodniczy SGGW w Warszawie. W okresie międzywojennym zaprojektowała wiele ogrodów i terenów zielonych, m.in. Toru Wyścigów Konnych na Służewcu, Kopca im. J. Piłsudskiego w Krakowie (wspólnie z inż. arch. R. Guttem), Rezerwatu w Zułowie (wspólnie z inż. arch. R. Guttem), Parku w Żelazowej Woli (wspólnie z prof. F. Krzywdą-Polkowskim). W okresie powojennym była zatrudniona w Pracowni Zieleni Biura Odbudowy Stolicy, zaprojektowała wiele terenów zielonych, m.in. Trasy W-Z, Parku na Powiślu, Sadów Żoliborskich, ogrodu Ambasady ChRL w Warszawie.

${ }^{47}$ M. Le śn iakowska: Zułów marszałka Piłsudskiego. Metafizyka miejsca czyli refleksje nad wyciętym lasem, „Arché: kultura, twórczość, krytyka” nr 17/18, 1998, s. 33; Dąb ten przetrwał do dna dzisiejszego.

48 Tamże: s. 34-35.

${ }^{49}$ Tamże: s. 33. 
indywidualnych odwiedzało miejscowość, w której urodził się Józef Piłsudski. Ze względu na to, że Rezerwat znajdował się w odległości około kilometra od linii Podbrodzie - Łyntupy - Królewszczyzna, Dyrekcja Okręgowa Kolei Państwowych w Wilnie podjęła decyzję o otwarciu w Zułowie przystanku osobowego - w odległości 14 km od stacji Podbrodzie w kierunku na Łyntupy.

W 1935 r. zbudowano w Zułowie, według projektu Genello, niewielki budynek stacyjny. Inspiracją projektu przystanku była zabytkowa kapliczka na cmentarzu w Zułowie ${ }^{50}$. W historyzującej realizacji budynku widzimy charakterystyczne elementy architektury polskiego dworu. Według planów przystanek Zułów w układzie przestrzennym miał stanowić bramę do tzw. Rezerwatu Zułowskiego. Paradoksalnie była to chyba ostatnia „narodowa” realizacja w polskiej architekturze kolejowej, jej historyzujący styl był zdeterminowany charakterem miejsca i historycznym nawiązaniem.

W artykule, zamieszczonym w „Kolejowym Przeglądzie Technicznym”, formę architektury budynku przystanku w Zułowie opisał znany architekt, m.in. twórca Hali na Koszykach w Warszawie, inż. Juliusz Dzierżanowski, ukazując także inspirację Genello:

W związku z zamierzoną odbudową Zułowa, który, jako dawna siedziba rodziny Piłsudskich, ma być zachowany w formie rezerwatu narodowego i może stać się celem licznych wycieczek turystycznych, należało pomyśleć o budowie odpowiedniego dworca na przystanku w Zułowie. Projekt wykonany został przez arch. Henryka Genello. W kompozycji ogólnej daje się zauważyć dążenie autora do czerpania motywów lokalnych. Pomysł całości niewielkiego dworca, z dachem o typie polskim i okapem przyźbowym oraz kolumienkami podcieniowymi, daje rozwiązanie, mające wiele cech wspólnych z pełną swoistego wdzięku starą kapliczką na cmentarzu wiejskim w Zułowie, której podobiznę podajemy na okładce. W ten sposób autor szczęśliwie nawiązał swój projekt do tradycji budownictwa miejscowego. Prostota i skromność ogólnej kompozycji staje się niejako symbolem pełnego prostoty osobistego życia ś.p. Marszałka ${ }^{51}$.

Oś przystanku osobowego Zułów wyznaczał środek budynku, był to km 13,426 linii Podgrodzie - Królewszczyzna ${ }^{52}$. Murowany dworzec w Zułowie został zrealizowany w formie prostego parterowego budynku o wydłużonej bryle, nad którą dominował czterospadowy, wysoki dach. De facto wnętrze budynku składało się z dwóch części przedzielonych na osi przejściem. W pierwszej zlokalizowano mieszkanie służbowe kasjera biletowego (pokój, kuchnia, dwie sienie z niezależnymi wejściami), w drugiej mieściła się kasa biletowa i poczekalnia z wejściem od strony rozdzielają-

${ }^{50}$ J. Dzierżan owski: Dworzec kolejowy w Zułówie, „Kolejowy Przegląd Techniczny” 1935, nr 7, s. 3.

51 Tamże: s. $1-3$.

52 Tamże: s. 2, plan. 
cego przejścia. Ze względu na ruch podróżnych okienko kasy biletowej umieszczono po prawej stronie pod zadaszeniem, bezpośrednio w przejściu rozdzielającym. Obie części budynku miały niezależne ogrzewanie piecowe. Przylegały do nich skrajne, symetrycznie usytuowane poczekalnie letnie. Elewacja frontowa budynku (od strony podjazdu) została ukształtowana symetrycznie poprzez zastosowanie prostego programu architektonicznego. Przed wejściem do budynku wymurowano trzystopniowe schody, które prowadziły do portyku wgłębnego, akcentującego centralną oś fasady. Po obu stronach wejścia na tejże tynkowanej na biało elewacji, wykonano otwory okienne z czterodzielnymi oknami, a także umieszczono uchwyty na flagi państwowe. W centralnej części dachu od strony fasady projektant umieścił okno powiekowe, które podkreślało dodatkowo symetryczny układ elewacji.

Zarówno elewacja budynku od strony torów, jak i elewacje boczne (mieszczące poczekalnie letnie) zostały ukształtowane poprzez zastosowanie podcieni, które obiegały budynek z trzech stron. Podcienia te zostały ograniczone ciągiem prostych, równomiernie rozstawionych kolumn z kapitelem kostkowym. W centralnej osi elewacji od strony torów umieszczono pseudoryzalit zwieńczony szczytem, pokrytym deskowaniem z siedmioma otworami wentylacyjnymi w formie rombu (motyw inspirowany zapewne lokalną architekturą Wileńszczyzny) i umieszczono na nim emaliowaną tablicę z czarnym napisem „Zułów” na białym tle. Po obu stronach budynku umieszczono wyżej wspomniane poczekalnie letnie, których przestrzeń została ograniczona trzema filarami oraz treliażami na dzikie wino. Budynek dworca nakryto czterospadowym dachem, z wydatnym okapem. Dodatkowo pseudoryzalit, znajdujący się w elewacji od strony torów, nakryto osobnym dachem dwuspadowym. Połacie dachu pokryto podwójnie ceramiczną dachówką karpiówką, układaną w tzw. łuskę.

Szczególne znaczenie w układzie dworca w Zułowie miało centralnie ulokowane, otwarte przejście, akcentujące oś założenia rezerwatu, które prowadziło wprost z peronu na plac dworcowy (z owalnym klombem) i zostało usytuowane na osi drogi do Zułowa, prowadzącej do przyszłego założenia:

Z budynku stacyjnego wychodzi się na obszerny podjazd, przybrany kwietnikiem, do traktu Wilno - Święciany, stanowiącego część Szlaku Marszałka Józefa Piłsudskiego. Szlak ten biegnie przez całą Polskę od Krakowa, poprzez Kielce, Warszawę, Grodno i Wilno. Droga święciańska została całkowicie odremontowana, uzyskała wzorową nawierzchnię szutrową i wysadzona została drzewami. Po przejściu drogi przybywający wkraczają na drogę leśną, obrzeżoną granitowymi krawężnikami, a stanowiącą już element wprowadzający do pamiątkowego miejsca ${ }^{53}$.

Przystanek otwarto od letniego rozkładu jazdy 1936 r., od tego czasu zatrzymywały się na nim trzy pary pociągów osobowych relacji Podgrodzie - Królewszczyzna

${ }^{53}$ Zułów wczoraj i dziś, Warszawa 1938 r., s. 151. 
-Podgrodzie ${ }^{54}$. W ostatnim przedwojennym letnim rozkładzie jazdy 1939 r. na przystanku zatrzymywały się trzy pary pociągów relacji Podgrodzie - Królewszczyzna oraz jedna para relacji Podgrodzie - Łyntupy ${ }^{55}$.

Budynek przystanku Zułów został zniszczony podczas wojny lub w okresie stalinowskim, gdy cały teren rezerwatu zdewastowano, zacierając większość śladów po marszałku. Cudem przetrwał do naszych czasów złotolistny dąb zasadzony w miejscu jego narodzin. W 2000 r. dyrekcja Kolei Litewskich zawiesiła przewozy na linii Podbrodzie - Łyntupy - Królewszczyzna, trzy lata później przeprowadzono całkowitą rozbiórkę torów na tym odcinku. Nasypy kolejowe po rozebranej linii częściowo splantowano i przebudowano na lokalne drogi szutrowe ${ }^{56}$.

Około 1935 r., według projektu Genello, zbudowano również piętrowy budynek administracyjny na stacji postojowej Grochów ${ }^{57}$. Został zrealizowany w utylitarnej modernistycznej formie podporządkowanej technicznej funkcji stacji postojowej, jego elewację wykonano z szarej cegły silikatowej z oszczędnymi elementami dekoracji. Budynek został całkowicie zburzony przez Niemców podczas niszczenia infrastruktury kolejowej po upadku Powstania Warszawskiego. Bezpośrednio po wojnie odbudowano go w identycznej formie, zapewne według przedwojennej dokumentacji ${ }^{58}$.

Genello mógł być autorem projektów innych budynków zbudowanych na stacji postojowej Grochów w latach 1935-36, m.in. centralnej akumulatorni, warsztatów oraz kotłowni. Świadczy o tym fakt, iż wszystkie te obiekty, zbudowane z szarej cegły silikatowej, utrzymane były w spójnym stylu architektonicznym i miały identyczny detal.

W latach 30. XX w. rodzina Genellich zamieszkała w reprezentacyjnym domu dla wyższych urzędników Ministerstwa Komunikacji przy ul. Uniwersyteckiej 1 w Warszawie. W okresie międzywojennym Genello utrzymywał kontakty z włoskimi krewnymi, odwiedzając ich we Włoszech, podróżował salonką Ministerstwa Komunikacji ${ }^{59} .31$ grudnia 1937 r., po dziesięciu latach pracy w resorcie komunikacji, przeniesiono go na emeryturę $e^{60}$.

Podczas okupacji Genello nie pracował dla Niemców, aby się utrzymać, wykonał jedynie kilka projektów architektonicznych dla osób prywatnych ${ }^{61}$. Po upadku po-

${ }^{54}$ Urzędowy Rozkład Jazdy Pociągów Lato 1936 r., Tabela 538 Podgrodzie - Królewszczyzna, s. 305.

${ }^{55}$ Urzędowy Rozkład Jazdy Pociagów Lato 1939 r., Tabela 521 Podgrodzie - Królewszczyzna, s. 309.

${ }^{56}$ Informacja uzyskana dzięki uprzejmości pana Andrzeja Pileckiego z Wilna.

${ }^{57}$ Z. T u ch ols k i : Elektrowozownia Warszawa - Grochów zapomniany zabytek polskiej inżynierii i architektury II RP, „Kwartalnik Historii Nauki i Techniki”, 2017 nr 2, s. 101-124.

${ }^{58} \mathrm{~J}$. Andrzeje ws ki, J. Wardę cki: Konserwatorska Inwentaryzacja stacji postojowej Warszawa Grochów, BSKZ Warszawa 2015 r.

${ }^{59}$ Relacja wnuka Jerzego Genello z 12 lutego 2017 r.

${ }^{60}$ AZMI, sygn. 98/1955, Kwestionariusz Henryka Genello, 16 VII 1945 r., k. 1.

${ }^{61}$ Tamże. 
wstania został wywieziony przez Niemców z Warszawy. W 1945 r., bezpośrednio po powrocie do stolicy, w wieku 78 lat, przystąpił do pracy przy odbudowie zniszczonego kolejnictwa. Powrócił wraz z rodziną do swego przedwojennego mieszkania w kamienicy MK przy ul. Uniwersyteckiej $1^{62}$.

30 lipca 1945 r. został zatrudniony w charakterze pracownika umownego w celu prowadzenia prac architektonicznych w Biurze Planowania Ministerstwa Komunikacji, kierowanym przez zasłużonego przedwojennego inżyniera kolejowego Roberta Szajera ${ }^{63}$. W podlegającym mu Wydziale Projektów Kolejowych, kierował Referatem Architektonicznym ${ }^{64}$. W pierwszych powojennych latach, podobnie jak w II RP, kierował odbudową i budową nowych obiektów dworcowych, mieszkalnych i technicznych na całej sieci PKP. 20 lipca 1946 r. został odznaczony za zasługi przy odbudowie kolejnictwa Srebrnym Krzyżem Zasługi ${ }^{65}$.

1 kwietnia 1947 r. przeniesiono go do Wydziału Projektów i Studiów Departamentu Budowy i Utrzymania $\mathrm{MK}^{66} .26$ lipca 1948 r. w związku ze zniesieniem Wydziału Projektów i Studiów Departamentu Budowy i Utrzymania Kolei MK, Genello został przeniesiony do Biura Projektów w Ministerstwie Komunikacji ${ }^{67}$. W wyniku rozwoju ciężkiej choroby, zmarł 1 października 1948 r. w Szpitalu Dzieciątka Jezus w Warszawie i został pochowany na Cmentarzu Brudnowskim ${ }^{68}$.

Henryk Genello i Hipolit Hryncewicz ściśle współpracowali jako architekci Dyrekcji Kolei Państwowych w Wilnie. W latach 20. XX w. zaprojektowali na kresach II RP niespełna 50 budynków dworcowych w stylu narodowym, które w większości zrealizowano według kilku opracowanych przez nich powtarzalnych projektów. Budynki te zapewne ze względu na normatywy kolejowe były zbliżone pod względem układu funkcjonalnego i architektury do dworców projektu Romualda Millera i Eugeniusza Szrettera, zrealizowanych na terenie Dyrekcji Kolei Państwowych w Warszawie.

W tym miejscu należałoby dokonać porównania twórczości Henryka Genello i Romualda Millera. Obaj architekci tworzyli w tym samym okresie początkowo w stylu narodowym, w podobny sposób pod koniec lat 20. XX w. ich projekty nosiły już silne cechy modernizmu, by w latach 30 . XX w, stać się całkowicie funkcjonalistyczne. Narzucające się porównanie utrudnia jednak brak źródeł, o ile realizacje

${ }^{62}$ Tamże k. 1, verte.

${ }^{63}$ AZMI, sygn. 98/1955, Pismo ministra komunikacji do inż. Henryka Genello z 8 VIII 1945 r. oraz pismo Biura Planowania MK do Biura Personalnego MK z 16 VIII 1945 r.

${ }^{64}$ Ministerstwo Komunikacji, Spis abonamentów telefonicznych Ministerstwa Komunikacji, ważny od dnia 4 maja 1946 r., s. 16.

${ }^{65}$ Uchwałą prezydium Krajowej Rady Narodowej z 20 lipca 1946 r., „Monitor Polski” nr 25 z 24 II 1947 r., poz. 118, s. 4.

${ }^{66}$ AZMI, sygn.. 98/1955, Pismo Biura Personalnego MK do inż. Henryka Genello z 2 VI 1947 r.

${ }^{67}$ Tamże. Pismo ministra komunikacji do Henryka Genello z 26 VII 1948 r.

${ }^{68}$ Tamże, Odpis skrócony aktu zejścia Henryka Genello, wydany 4 X 1948 r.; Relacja wnuka Jerzego Genello z 12 lutego 2017 r. 
kolejowe Millera w większości są znane, to w przypadku Genello obecny stan badań uniemożliwia nawet sporządzenie katalogu jego realizacji. We wczesnym okresie twórczości projektował on wspólnie z Hryncewiczem, więc bez oryginalnej dokumentacji nie jest również możliwe określenie autorstwa poszczególnych projektów.

Niezwykle wartościową realizacją Genello i Hryncewicza był reprezentacyjny „modernizowany" dworzec na stacji granicznej w Stołpcach, istotny dla ewolucji polskiej architektury kolejowej w II RP. Na przełomie lat 20. i 30. XX w. Genello zaprojektował dworce na linii Ustron - Wisła, były one zrealizowane w stylu narodowym, częścowo drewniane inspirowane architekturą zakopiańską. Dworce murowane na tej linii miały proste pozbawione detalu elewacje o cechach modernistycznych, ich dachy były czterospadowe kryte dachówką. Analiza formy dworców zbudowanych na tej linii napotyka również na istotną przeszkodę - jedyna informacja o autorstwie Genello pochodzi z ustnej relacji jego wnuka i nie ma źródłowego potwierdzenia.

Inną wartościową realizacją Genello z 1935 r. był niewielki budynek przystanku kolejowego Zułów - który w II RP miał charakter memoratywny dla instytucjonalnie kształtowanego kultu marszałka Piłsudskiego. Prawdopodobnie była to ostatnia „narodowa” realizacja w polskiej architekturze kolejowej. Budynki jego autorstwa zrealizowane $\mathrm{w}$ tym stylu charakteryzowały się prostotą, czystą formą, nawiązywały do lokalnych odmian i motywów architektury polskiej. Narodowa architektura budynku zrealizowanego w okresie, gdy w polskiej architekturze dominował modernizm, była podyktowana charakterem miejsca i historycznym nawiązaniem.

Analiza twórczości Genello wykazuje, że niewątpliwie lepiej odnajdywał się projektując we wcześniejszym, historyzującym stylu, tworząc własną jego odmianę inspirowaną motywami lokalnymi. Jego późniejsze funkcjonalne realizacje charakteryzują się prostotą, oszczędną i surową formą elewacji pozbawionych detalu.

Następne realizacje Genello wpisywały się już w dominujący również w architekturze kolejowej lat 30. XX w. nurt architektury modernistycznej. Na obecnym etapie badań praktycznie niemożliwe jest również ścisłe określenia autorstwa innych budynków na stacji postojowej Grochów, które prawdopodobnie zaprojektował Genello. Nie można także odpowiedzieć na pytanie czy Genello zaprojektował jakieś budynki kolejowe w okresie powojennym.

Henryk Genello niewątpliwie należał do najważniejszych architektów kolejowych II RP, od 1932 r. pracując na stanowisku radcy Ministerstwa Komunikacji, od strony administracyjnej i technicznej kształtował architekturę kolejową II RP. Identyczną funkcję pełnił również w pierwszych latach powojennych. Ze względu na szkicowy charakter, materiał ten powinien stać się wyjściem do dalszych badań jego architektury, prowadzonych także w archiwach Litewskich i Białoruskich. 


\section{Podziękowania}

Autor artykułu serdecznie dziękuję pani Małgorzacie Jaworskiej, panu Michałowi Jerczyńskiemu, prof. Grzegorzowi Nowikowi oraz panu Andrzejowi Bileckiemu z Wilna, za wnikliwą lekturę tekstu i cenne uwagi. Słowa podziękowania kieruję również do pana Jerzego Genello, za relację dotyczącą dziadka i historii rodziny.

\section{BIBLIOGRAFIA}

Archiwum Zakładowe Ministerstwa Infrastruktury (dalej AZMI), sygn. 98/1955, Akta osobowe inż. Henryka Genello. $\mathrm{nr} 47$.

А.С. Евгений Шреттер - зодчий Серебряного века, „Архитектурное наследство” 2007,

J. A n d r z e j e w s k i, J. Wa r d ę c ki : Konserwatorska Inwentaryzacja stacji postojowej Warszawa Grochów, Warszawa 2015.

H. Bilewicz: Włodzimierz Podlewski: architektura i sztuka. W roku jubileuszu stulecia urodzin, Gdańsk 2008 r.

J. Dzierżanowski: Dworzec kolejowy w Zułówie, „Kolejowy Przegląd Techniczny” 1935, nr 7.

Dziesięciolecie Polskich Kolei Państwowych 1918-1928, Warszawa 1928.

http://www.archiwumkorporacyjne.pl/index.php/muzeum-korporacyine/ryga/k-welecja/A Archiwum Korporacyjne. Archiwum i Muzeum Polskich Korporacji Akademickich. Rok założenia 1974 - 1988 - 2001.

P.J. Ja m s ki : Pocztówki z Kresów przedwojennej Polski, Warszawa 2012.

M. Je rc zyńs ki : Architektura obiektów kolejowych na liniach kolei Warszawsko-Wiedeńskiej - ewolucja stylu od 1845 r. do dziś, referat na Sesji popularno-naukowej „Dziedzictwo Wiedenki", Muzeum Techniki i Przemysłu NOT, 11 czerwca 2015 r.

Kolej Śląska Cieszyńskiego, http://kolejcieszyn.pl/191.php?s=wislaob, dostęp 28 marca $2017 \mathrm{r}$.

M. Le śn i a ko w s ka: Zułów marszałka Piłsudskiego. Metafizyka miejsca czyli refleksje nad wyciętym lasem, „Arché: kultura, twórczość, krytyka” 1998, nr 17/18.

Nowy dworzec kolejowy, „Goniec Śląski” nr 13, 17 styczeń 1933 r.

Obiekty kolejowe: układy przestrzenne, architektura, elementy techniki, red. W. C z a r n e cki , M. Pron i e ws k i, Białystok 2005.

Piękne użyteczne zbędne... Obiekty kolejowe w Polsce, red. M. Kw a p i a s, D. Kell e r, Rybnik 2016.

Przystań siedziba Towarzystwa Wioślarskiego w Wilnie, „Sport Wodny” 1926, nr 5.

M. P s z c z ół ko w s k i : Architektura użyteczności publicznej II Rzeczypospolitej 1918-1939. Funkcja, Łódź 2015.

M. P s z c zół kow s ki : Kresy nowoczesne. Architektura na ziemiach wschodnich II Rzeczypospolitej 1921-1939, Łódź 2016. 
Российский Медицинский список на 1908 год, s. 92; Россійскій Медицинскій Списокъ на 1914 годъ, http://personalhistory.ru/papers/rms1914.htm, dostęp 25 marzec 2017 r.

Ruch służbowy w Ministerstwie Komunikacji i Dyrekcjach Okręgowych Kolei Państwowych Dziennik Urzędowy Ministerstwa Komunikacji 1932, nr 12 i 17

G. Ru s z c zy k: Drewniane kościoły w Polsce 1918-1939. Tradycja i nowoczesność, Warszawa 2001.

A. S kali mows ki, Z. T u chols ki: Modernistyczne wiaty i przystanki kolejowe warszawskiego Węzła Kolejowego: o konieczności ochrony konserwatorskiej, „Ochrona Zabytków” 2010, nr $1-4$.

Słownik artystów polskich i obcych w Polsce działających, malarze rzeźbiarze graficy, t. II, Warszawa 1975.

M. S oł ty s i k: Na styku dwóch epok. Architektura gdyńskich kamienic okresu międzywojennego, Gdynia 2003.

K. Ta b a k: Romualda Millera droga do modernizmu. Od dworca kolejowego w Gdyni po warszawskie realizacje lat 30. XX w.; [w:] Trwałość? Użyteczność? Piękno? Architektura dwudziestego wieku w Polsce, Wrocław 2011, s. 46-47.

Urzędowy spis lekarzy uprawnionych do wykonywania praktyki lekarskiej, lekarzy dentystów, dyplomowanych farmaceutów oraz aptek w Rzeczypospolitej Polskiej, Warszawa 1931.

S. Wasilewski: Pokaz Ministerstwa Komunikacji na Powszechnej Wystawie Krajowej w Poznaniu, „Inżynier Kolejowy” 1929, nr 7.

J. Wo łk a n o w s k i : Otwarcie nowego dworca na st. Stołpce, „Inżynier Kolejowy” 1926, nr 11.

Zułów wczoraj i dziś, Warszawa 1938. 